\title{
Differential Diagnosis of Anechoic Images in Endobronchial Ultrasound
}

\author{
Endobronşial Ultrasonda Anekoik Görüntülerin Ayırıcı Tanısı
}

Ester Cuevas', Yuliana Pascual-González , Nikos Koufos² ${ }^{2}$ Antoni Rosell, Noelia Cubero

\begin{abstract}
In the present pictorial study, we report on four different cases with Endobronchial Ultrasound anechoic images, taken during a mediastinal lymph node study. Each anechoic image had a nodal coagulative necrosis sign. Although the anechoic images had similar characteristics in all cases, the final pathology report was different, with two cases positive for malignancy, one case showing a benign tumor of thyroid gland origin, and one case with tuberculosis. All patients signed informed consent for investigation with the EBUS technique. The procedure was performed in accordance with the regulations of our hospital, and following the usual technique followed in diagnostic mediastinal pathology studies.
\end{abstract}

Key words: EBUS-TBNA, lymph nodes, anechoic images, hypoechogenicity, heterogeneity.

\section{Özet}

Bu görsel ağırlıklı sunuda, mediastinal lenf bezi çalışmaları sırasında, endobronşial ultrasonda anekoik görüntü saptanan dört farklı olguyu sunuyoruz. Her bir anekoik görüntü, lenf bezinde koagülatif nekroz işareti vermekteydi. Tüm olgularda anekoik görüntüler benzer karakteristik özelliklere sahip olmasına rağmen, patoloji rapor sonuçları farklıdır. Iki olguda malignite pozitif idi, bir olguda tiroidden orijin alan benign tümör ve bir olguda da tüberküloz saptandı. Tüm hastalardan EBUS işlemi için yazılı onamlar alındı. Mediastinal patolojilerin tanısında gerekli genel incelemeleri takiben hastanemiz kurallarına göre işlemler yapıldı.

Anahtar Sözcükler: EBUS, Transbronşial iğne aspirasyonu, lenf bezi, anekoik görüntü, hipoekojenite, heterojenite.
${ }^{1}$ Hospital Universitari de Bellvitge, Respiratory Service, Hospitalet de Llobregat, Barcelona, Spain. IDIBELL - Institut d'Investigació Biomèdica de Bellvitge, Hospitalet de Llobregat, Barcelona, Spain.

${ }^{2}$ Mediterraneo Hospital, Interventional Pulmonary Unit - Respiratory Department, Athens, Greece.

3 Universitari Germans Trias i Pujol, Respiratory Service, Badalona, Spain.
${ }^{1}$ Bellvitge Üniversite Hastanesi, Göğüs Hastalıkları Kliniği, Llobregat Hastanesi, Barselona, İspanya. IDIBELL - Bellvitge Biyomedikal Araştırma Enstitüsü, Llobregat Hastanesi, Barselona, İspanya.

${ }^{2}$ Mediterraneo Hastanesi, Girişimsel Akciğer Ünitesi - Solunum Anabilim Dalı, Atina, Yunanistan.

${ }^{3}$ Trias i Pujol Alman Üniversitesi, Göğüs Hastalıkları Kliniği, Badalona, İspanya

Submitted (Başvuru tarihi): 08.08.2019 Accepted (Kabul tarihi): 24.08.2019

Correspondence (Iletişim): Ester Cuevas, Hospital Universitari de Bellvitge, Respiratory Service, Hospitalet de Llobregat, Barcelona, Spain. IDIBELL - Institut d'Investigació Biomèdica de Bellvitge, Hospitalet de Llobregat, Barcelona, Spain.

e-mail: ester.cuevas@bellvitgehospital.cat 
Endobronchial ultrasound (EBUS) allows the visualization of mediastinal and hilar structures with real-time cytological and histological sampling (1). The procedure currently has a place in most scientific society guidelines for the diagnosis of mediastinal lymphadenopathies and lung cancer staging (2). During the procedure, the rapid detection and differentiation of a target lesion between adjacent reactive, nondiagnostic nodes may help in reaching faster and safer results. Accordingly, different ultrasonic patterns have been studied aiming to reach a better distinction between benign and malignant nodes before node sampling, based on such parameters as lymph node size, shape, presence of central necrosis, etc. (3). In this small case series we present different diagnostic scenarios of anechoic lesions detected by EBUS, and compare the image characteristics with the final pathology result.

\section{CASE}

Case 1: A 70-year-old male with severe COPD was diagnosed with squamous cell lung carcinoma of the right upper lobe following fine needle aspiration (FNA) under CT guidance. A PET-CT was performed, and several hypermetabolic right lower paratracheal and hilar nodes were detected (stations 4R and 10R). During EBUS-TBNA, the nodes were described as oval in shape, with a $12 \mathrm{~mm}$ short-axis diameter, ill-defined borders and several heterogeneous, avascular and anechoic areas (Figure 1A). The EBUS-TBNA samples ( $22 \mathrm{G}$ needle) showed a fibrous material with a cloudy appearance, compatible with coagulative necrosis. The final pathology examination revealed squamous cell lung carcinoma with areas of necrosis.

Case 2: A 67-year-old female, ex-smoker was diagnosed with stage IIIA lung adenocarcinoma. During EBUS-TBNA staging, a subcarinal adenopathy was found (PET positive nodes). The detected nodes were oval in shape, $13 \mathrm{~mm}$ in short-axis diameter, had well-defined borders, were highly heterogeneous and had areas of avascular hypoechogenicity (Figure 1B). The samples obtained (via a 22G needle) contained a stringy, liquefied mucoid material of yellow/red color. The final pathology examination revealed an invasive mucinous lung adenocarcinoma.

Case 3: A 47-year-old female was investigated for a lymphoproliferative syndrome. A chest CT scan was suggestive of a multinodular goiter with the co-presence of an upper paratracheal lymphadenopathy. The FNA sample under $\mathrm{CT}$ guidance revealed benign thyroid cells, and an EBUS-TBNA was performed to further investigate the enlarged lymph nodes (station 2L). The largest detected node was round in shape with a $6 \mathrm{~mm}$ short-axis diameter had well-defined borders, was heterogeneous, and had avascular and anechoic areas (Figure 1C). The EBUSTBNA samples (22G needle) contained a non-fibrous bloody material with a greasy appearance. The final pathology examination showed a crazy paving pattern with cracking artifacts, suggestive of benign colloid nodular cells of thyroid gland origin.

Case 4: A 53-year-old female was admitted due to fever while undergoing triple immunosuppressive therapy following a recent heart transplantation. A PET-CT scan was performed showing small sized, hypermetabolic cervical, upper right paratracheal and right hilar nodes. An EBUSTBNA (22G needle) was performed, and round $2 R$ station nodes of $9.86 \mathrm{~mm}$ in the short-axis diameter with illdefined margins, heterogeneous, with hypoechogenic content suggestive of necrosis were detected (Figure 1D). The pathology examination revealed necrotizing granulomas compatible with tuberculosis, which was later confirmed by a Löwenstein-Jensen culture.

\section{DISCUSSION}

Endobronchial ultrasound sonographic features that are considered to be predictive of benign disease are small in size, round in shape and with well-defined margins, and present with a central hilar structure and nodal conglomeration. Signs of coagulation necrosis with a negative Doppler indicate the presence of necrotic tissue, and can commonly be found in malignant lymph nodes, as well as in benign diseases, such as tuberculosis (4).

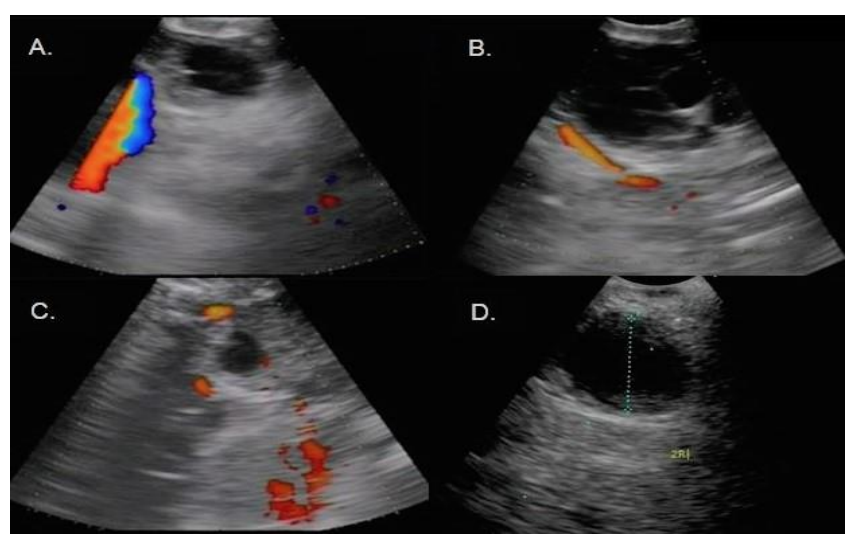

Figure 1: EBUS image of the anechoic, avascular lymph node, with higher heterogeneity (A), EBUS image of the anechoic, avascular and multi-lobulated lymph node (B), EBUS image of the lymph node with round anechoic areas (C), EBUS image of the lymph node with ill-defined margins, and heterogeneous and hypoechogenic content (D) 
Signs of nodal coagulation necrosis are caused by ischemia or hypoxia of the nodal cells, resulting in cell death and gradual digestion of the cellular remnants through the process of heterolysis (apoptosis induced by hydrolytic enzymes from the surrounding cells). The normal architecture of the lymph node can be maintained for several days, despite the central necrosis formation. The presences of anechoic areas observed via endobronchial ultrasound are more often malignant than benign (5).

Benign anechoic images are commonly caused by mediastinal cystic lesions described as homogeneous, with a negative Doppler flow or a heterogeneous background due to deposits of such materials as proteins, calcium oxalate crystals, blood or pus (6).

In conclusion, the sonographic features of lymph nodes can sometimes be a useful diagnostic tool during EBUSTBNA procedures. Signs of nodal coagulation necrosis can commonly be found in malignant lymph nodes, but cannot be considered as a specific sign, and so further histological sampling and analyses should be considered necessary before making a definitive diagnosis.

\section{CONFLICTS OF INTEREST}

None declared.

\section{AUTHOR CONTRIBUTIONS}

Concept - E.C., A.R., N.C., Y.P.G., N.K.; Planning and Design - E.C., A.R., N.C., Y.P.G., N.K.; Supervision E.C., A.R., N.C., Y.P.G., N.K.; Funding - E.C., A.R., N.C., Y.P.G., N.K.; Materials - E.C., A.R., N.C., Y.P.G., N.K.; Data Collection and/or Processing - E.C., Y.P.G.; Analysis and/or Interpretation - E.C., A.R., N.C., Y.P.G., N.K.; Literature Review - E.C., Y.P.G. N.C.; Writing - E.C., Y.P.G., A.R., N.C., N.K. Critical Review - E.C., Y.P.G., A.R., N.C., N.K.

\section{YAZAR KATKILARI}

Fikir - E.C., A.R., N.C., Y.P.G., N.K.; Tasarım ve Dizayn E.C., A.R., N.C., Y.P.G., N.K.; Denetleme - E.C., A.R.,
N.C., Y.P.G., N.K.; Kaynaklar - E.C., A.R., N.C., Y.P.G., N.K.; Malzemeler - E.C., A.R., N.C., Y.P.G., N.K.; Veri Toplama ve/veya İşleme - E.C., Y.P.G.; Analiz ve/veya Yorum - E.C., A.R., N.C., Y.P.G., N.K.; Literatür Taraması - E.C., Y.P.G. N.C.; Yazıyı Yazan - E.C., Y.P.G., A.R., N.C., N.K.; Eleştirel İnceleme - E.C., Y.P.G., A.R., N.C., N.K.

\section{REFERENCES}

1. Wahidi MM, Herth F, Yasufuku K, Shepherd RW, Yarmus $L$, Chawla M, et al. Technical aspects of endobronchial ultrasound-guided transbronchial needle aspiration: CHEST guideline and expert panel report. Chest 2016; 149:816-35. [CrossRef]

2. Vilmann P, Clementsen PF, Colella S, Siemsen M, De Leyn $P$, Dumonceau JM, et al. Combined endobronchial and oesophagal endosonography for the diagnosis and staging of lung cancer: European Society of Gastrointestinal Endoscopy (ESGE) Guideline, in cooperation with the European Respiratory Society (ERS) and the European Society of Thoracic Surgeons (ESTS) Endoscopy 2015; 47:cl. [CrossRef]

3. Lin $C K, Y \cup K L$, Chang LY, Fan HJ, Wen YF, Ho CC. Differentiating malignant and benign lymph nodes using endobronchial ultrasound elastography. J Formos Med Assoc 2019; 118(1 P+ 3):436-43. [CrossRef]

4. Vial MR, O'Connell OJ, Grosu HB, Hernandez M, Noor L, Casal RF, et al. Diagnostic performance of endobronchial ultrasound-guided mediastinal lymph node sampling in early-stage non-small cell lung cancer: A prospective study. Respirology 2018; 23:76-81. [CrossRef]

5. Lie $\mathrm{CH}$, Chao TY, Chung YH, Wang JL, Wang YH, Lin MC. New image characteristics in endobronchial ultrasonography for differentiating peripheral pulmonary lesions. Ultrasound Med Biol 2009; 35:376-81. [CrossRef]

6. Nachef Z, Harris K, Dhillon SS. Bronchogenic cyst: fluidthrill sign on endobronchial ultrasound. J Bronchol Intervent Pulmonol 2018;25:224-7. [CrossRef] 